\title{
Fuzzy Model for Assessing the Creditworthiness of Ukrainian Coal Industry Enterprises
}

\author{
Volodymyr POLISHCHUK ${ }^{1 *}$, Miroslav KELEMEN ${ }^{2 *}$, Igor POVKHAN ${ }^{1}$, \\ Martin KELEMEN, jr. ${ }^{2}$ and Igor LIAKH ${ }^{1}$
}

\begin{abstract}
Authors' affiliations and addresses:
${ }^{1}$ Faculty of Information Technology, Uzhgorod

National University, Uzhgorod, Ukraine

e-mail: volodymyr.polishchuk@uzhnu.edu.ua

e-mail: igor.povkhan@uzhnu.edu.ua

e-mail: igor.lyah@uzhnu.edu.ua

${ }^{2}$ Faculty of Aeronautics, Technical University of Košice, Košice, Slovakia

e-mail: miroslav.kelemen@tuke.sk

e-mail: martin.kelemen@tuke.sk

\section{*Correspondence:}

Volodymyr Polishchuk, Faculty of Information Technology, Uzhgorod National University, Zankovetska, 89a, 88000, Uzhgorod, Ukraine tel.: +380664207484

e-mail: volodymyr.polishchuk@uzhnu.edu.ua

Miroslav Kelemen, Faculty of Aeronautics, Technical University of Košice, ul. Rampová 7, 041 21, Košice, Slovakia

e-mail: miroslav.kelemen@ @uke.sk
\end{abstract}

\section{Funding information:}

Bilateral scholarship programs for 2021/2022

between the Ministry of Education and Science of Ukraine and the Ministry of Education, Science, Research and Sport of the Slovak Republic in the field of education (2021/114365:1-

A1510)/SAIA,n.o. SK-UA 2021

How to cite this article:

Polishchuk, V., Kelemen, M., Povkhan, I., Kelemen, M. jr. and Liakh, I. (2021). Fuzzy Model for Assessing the Creditworthiness of Ukrainian Coal Industry Enterprises. Acta Montanistica Slovaca, Volume 26 (3), 444-454

DOI:

https://doi.org/10.46544/AMS.v26i3.05

\begin{abstract}
The actual scientific research of development of information models of representation of fuzzy knowledge at an estimation of creditworthiness of the enterprises of the coal industry of Ukraine and perfection of a fuzzy mathematical model of an estimation of creditworthiness of the enterprises is carried out. Based on settheoretic analysis, a set of 11 criteria for assessing the creditworthiness of enterprises is formed and divided into 3 groups: indicators of financial stability, analysis of profits and losses, the efficiency of enterprise management. A membership function is constructed for each criterion, which will reveal the uncertainty in the input data, leading to a normalized form for comparison. To construct membership functions, a study was conducted to determine their type and type, as well as the parameters of membership functions based on the experience of credit experts and data sets on indicators, using real financial reports of Ukrainian coal industry enterprises for 2020. The improved fuzzy mathematical model for assessing the creditworthiness of enterprises, which reveals the vagueness of input data, derives the assessment of creditworthiness based on the reasoning of the decision-maker (DM), determines the linguistic level of ability to repay financial obligations on time. Based on the built model, a general six-step algorithm is constructed, which can be quickly implemented in the software product. The developed information model and the improved fuzzy mathematical model were tested on real data of credit assessment of the Lvivugol State Enterprise of Ukraine. Outcome, models, and approaches to presenting fuzzy knowledge for indicators of creditworthiness assessment of Ukrainian coal industry enterprises, which will be a model for other countries to follow.
\end{abstract}

\section{Keywords}

Coal industry, fuzzy knowledge, creditworthiness, applied informatics, decision-making.

(c) 2021 by the authors. Submitted for possible open access publication under the terms and conditions of the Creative Commons Attribution (CC BY) license (http://creativecommons.org/licenses/by/4.0/). 


\section{Introduction}

Since the industrial revolution, the world economy has relied mainly on fossil fuel consumption. Coal is used as a technological, energy-technological, and energy raw material in the production of coke and semi-coke to obtain a large number of chemical products (naphthalene, phenols, pitch, etc.), which produce fertilisers, plastics, synthetic fibres, varnishes, paints, etc. (Xu et al., 2020). Today, there are various schemes of non-energy use of coal-based on thermochemical, chemical, and other processing in order to fully integrate them and ensure environmental protection (Bialy et al., 2020). To meet the needs of the economy, Ukraine annually uses about 100 million tons of coal, of which almost 80 million tons are extracted by Ukrainian enterprises (Smyrnov et al., 2011).

The results of the analysis of world energy development trends show that in the structure of world reserves of fossil fuels, coal accounts for 67 per cent, oil - 18, and natural gas -15 per cent. In Ukraine, these figures are 95.4 per cent, 2, and 2.6 per cent, respectively. The total volume of domestic coal reserves is about 117.5 billion tons, of which industrial in existing mines -6.5 billion tons, of which almost 3.5 billion tons - thermal coal (Marko et al., 2020).

Geographically, coal reserves are concentrated in five regions of Ukraine: Donetsk, Luhansk, Dnipropetrovsk, Lviv, Volyn. Coal is distributed in the Donetsk and Lviv-Volyn basins, brown coal in the Dnieper, Donetsk basins, the Dnieper-Donetsk basin, and the Transcarpathian coal-bearing area.

Ukraine is one of the twenty leading countries in the world in terms of coal production but is significantly behind most of them in terms of economic indicators of coal production (World Coal Imports by Country, 2021). The vast majority of coal mines and sections are unprofitable. The level of wages is the lowest among other branches of the fuel and energy complex. As a result, the shortage of personnel at the coal industry enterprises is growing. In addition, the unsatisfactory state of the industry is due to a number of objective and subjective factors. Objectives include the complexity of mining and geological conditions of coal mining, low technical level of coal mining and coal processing enterprises, a high degree of physical and moral depreciation of fixed assets, subjective associated with limited investment resources, inefficient industry management system and lack of market pricing mechanism for coal products.

In order to improve the state of the industry and increase the rate of production, it is necessary to attract investment in the coal industry of Ukraine (Kelemen et al., 2020). Therefore, there is an urgent task to support decision-making assessing the creditworthiness of enterprises in conditions of risk and uncertainty. Solving this problem requires theoretical and multiple studies and the construction of adequate innovative mathematical models that will increase the validity of decisions under fuzzy, incomplete, and subjective input data.

In response to all these facts, it was decided to conduct a topical study, the main purpose of which is to develop information models for the presentation of fuzzy knowledge in assessing the creditworthiness of the Ukrainian coal industry and improve the fuzzy mathematical model for assessing the creditworthiness of enterprises.

\section{Literature review}

Next, we will carry out an analytical review of technologies for assessing the creditworthiness of enterprises.

Banking legislation focuses on the unification of banking legislation within the European Community and the supervision of banking activities in accordance with the requirements of the Basel Committee. The main problem of bank standardisation is an effective risk management system. These international standards are the Basel Accords (Principles for the Management of Credit Risk, 2000; International Convergence of Capital Measurement and Capital Standards, 2004; International Regulatory Framework for Banks, 2010). Research on creditworthiness (Pestova \& Mamonov, 2013; Chernikova et al., 2015) usually focuses on problem loans, which determine the quality of the loan portfolio (Kjosevski \& Petkovski, 2017; Fainstein \& Novikov, 2011). Approaches to estimation are usually based on methods of econometric and statistical analysis (Pestova \& Mamonov, 2013; Kjosevski \& Petkovski, 2017), where the initial data for analysis are deterministic, and the dependencies are mainly described by linear equations. When big data or complex nonlinear relationships are described (Kotsovsky \& Batyuk, 2020), then stochastic fuzzy machine learning methods are often used (Shalev-Shwartz \& Ben-David, 2014; Leo et al., 2019; Orlova, 2021).

Many scientists classify the methods of creditworthiness, taking into account various factors, approaches, the basis of calculations, etc. General classification of existing methods of creditworthiness of enterprises (Kovalov, 2004): classification (statistical) valuation methods, which include rating (scoring systems) and bankruptcy forecasting models; models of complex analysis (expert assessments).

The value of the rating is that it evaluates not only quantitative indicators but also qualitative ones. In practice, each bank chooses its own coefficients and methods of their calculation (Kravchenko, 2021). The creditworthiness of enterprises is determined in points, which are translated into a certain class (rating). Among the scientists who have studied rating systems, we can highlight the following: J. Shim, J. Siegel, B. Needles, G. Anderson, D. 
Caldwell, E. Reed. Each of them identified different indicators from the following groups: liquidity, profitability, long-term solvency, and indicators based on market conditions. The advantage of the rating system is its simplicity.

Among the models of multiple discriminant analysis, we can distinguish the following: V. Lis, models of Taffler and Tishaw, Springgate, O. Tereshchenko, Davidova-Belikova, Saifullin-Kadykov, M. Fedotova, Altman, Cheser, and others. (Polishchuk \& Malyar, 2018). For example, back in 1977, Altman, Holdeman, and Narayan built a second-generation model (the Altman Z-model) with some improvements over the original Z-Score. The purpose of this study was to build, analyse and test a new classification model of bankruptcy, which objectively considers the bankruptcy of entities. The Chesser model is designed to predict an entity's default on a loan agreement. That is any deviations that may affect the non-compliance with the planned terms of the contract. The first Russian experience in applying the Altman approach is the developed Davydova-Belikov model (Davydova \& Belikov, 1999). In 2012, the National Bank of Ukraine and O. Tereshchenko built a multifactorial discriminant model for calculating the integrated indicator of the financial condition of an economic entity (Tereshchenko, 2012).

We can distinguish one of the models, based on the classification tree, "recursive partitioning" (recursive partitioning) proposed by M. Friedman, E. Altman, and D. Kao (Frydman et al., 1985). This model allows you to develop rules for granting credit when building a "classification tree" in order to reject bankrupt entities. The accuracy of classification of this method is $90 \%$.

The method, based on the analysis of cash flows (Endovytskyy \& Bocharova, 2005), allows you to use the ratios calculated on the basis of turnover of liquid assets, inventories and short-term debt by calculating the net balance of various income and expenditures for a certain period.

The presence of factors of the weak structure of the task of investment decision-making, uncertainty, expert assessments, subjective advantages of DM, gives grounds to say that in the system of investment decision support should be processed not only data but also knowledge, and in both cases should be taken into account uncertainty factor.

Appropriate mathematical approaches are needed to create such systems. Fuzzy models, methods, and algorithms designed to process fuzzy data and knowledge can find the widest application here. In order to model the uncertainty in work, fuzzy-multiple descriptions and fuzzy inferences are used (Meng, 2021). For example, Zaychenko (2008) discusses the general ideas and benefits on which modern views on the use of fuzzy logic in decision support systems are based. The works (Kelemen et al., 2020; Kelemen et al., 2021) present the use of fuzzy logic in various fields of application, which shows the relevance of this theory. In the works (Polishchuk, 2018; Kelemen et al., 2019), the rationality of using fuzzy sets and functions belonging to the evaluation of investment and startup projects is proved. The authors have already raised the issue of assessing the creditworthiness of enterprises using fuzzy mathematics in their works (Malyar \& Polishchuk, 2012; Polishchuk \& Malyar, 2018)

Nevertheless, to date, no comprehensive study has been presented to assess the creditworthiness of Ukrainian coal industry enterprises with recommendations for building a fuzzy model for other countries to follow. Therefore, the value of our study is to construct information models for the presentation of fuzzy knowledge of creditworthiness assessment for the coal industry, based on data from their activities for adequate comparison in the Ukrainian conditions of operation.

\section{Material and Methods}

Formal problem statement. Suppose we have some enterprise of the coal industry $P$. To assess its creditworthiness, you need to get a lot of input data $V=\left(V_{1}, V_{2}, \ldots, V_{s}\right)$, using financial statements, central bank requirements, and additional sources. Based on the set of input data, we calculate the value of information criteria $K_{1}, K_{2}, \ldots, K_{m}$.

Since the input data are of different nature, carry both quantitative and qualitative information, and the value of the information evaluation criteria is quantitative, at this stage, there is a problem of formalizing the input data. To solve this problem, the methodology of fuzzy knowledge processing will be used, which is based on the mathematical apparatus of fuzzy sets.

Let $K=\left\{\left(K_{i}, \mu\left(K_{i}\right)\right), i=1,2, \ldots, m\right\}$ be a fuzzy set of efficiency criteria used to assess the creditworthiness of enterprises. $\mu\left(K_{i}\right)$ an estimate of the one-dimensional membership function of the corresponding criterion, built by information modelling of the representation of fuzzy knowledge.

Next, you need to build a mathematical model of decision-making. This model, based on the received estimations, should define for the considered enterprise of the coal industry an estimation of the level of creditworthiness which we will designate $D=\left(D_{1}, D_{2}, \ldots, D_{t}\right)$. normally, such a model can be written as an operator:

$$
M: K(V) \rightarrow D
$$


This operator analyses an object with $n$ inputs and one output.

The set of levels can be represented by the ratings of one of the world's leading rating agencies, Fitch Ratings and denote it $D=(A A A, A A, A, B B B, B B, B, C C C, C, R D, D)$ (Fitch Ratings: Credit Ratings \& Analysis for Financial Markets, 2021).

Because today the demand for assets outweighs the ability to satisfy all entities, so there is a problem of choosing companies for lending or investment projects, which is modelled using multi-criteria selection tasks.

The mathematical model for solving this problem can be represented as a multi-criteria choice problem and formulated as follows. Let $P=\left\{P_{1}, P_{2}, \ldots, P_{n}\right\}$ be a set of alternatives, i.e., coal industry enterprises that have applied to a financial institution to obtain a loan or finance an investment project. Their solvency is determined by many indicators, which are assessed using a set of performance criteria. The choice problem is formulated as follows: to arrange the set $P$, to determine the most reliable enterprises, relative to the set of evaluations of the criteria $K$.

By solving the selection problem in this way, we get a ranked set of coal companies in terms of criteria. To minimise banking risks and generate projected income, the decision-maker has the opportunity to select the most reliable entities for lending or financing investment projects.

Research and development of information models for the presentation of fuzzy knowledge of assessing the creditworthiness of enterprises

To construct the input data using the criteria for assessing the creditworthiness of coal enterprises, it is proposed to use the apparatus of fuzzy sets to build models for the representation of fuzzy knowledge. The apparatus of fuzzy sets requires the person making the decision to compare not point probabilistic estimates but at an interval that shows the corridor of values of the forecast parameters. The convenience of such methods is manifested in increasing the degree of validity of decisions, as it considers all possible scenarios of development, depicting a continuous spectrum.

The system set-theoretic model of the problem of representation of fuzzy knowledge can be represented as follows:

$$
\{P, K, M F, Z F \mid D\}
$$

Where: $P$ coal industry enterprise or set of enterprises; $K$ information model of criteria (groups of criteria) for assessing the creditworthiness of enterprises by various factors of influence, based on data sets $V$ (expert knowledge, quantitative data); $M F$ the model of construction of membership functions for assessing the creditworthiness of enterprises; $Z F$ is a fuzzy integrated model for assessing the creditworthiness of enterprises. As a result, we obtain an aggregate initial estimate $D$ of the object of study $P$.

A set-theoretic analysis was performed, based on which a set of criteria for assessing the creditworthiness of coal industry enterprises was determined and classified into three groups:

- Group $G_{1}$ the indicators of financial stability: $K_{1}$ - instant liquidity ratio; $K_{2}$ - current liquidity ratio; $K_{3}$ - total liquidity ratio; $K_{4}$ - coefficient of financial independence; $K_{5}$ - coefficient of maneuverability of own funds;

- $\quad$ Group $G_{2}$ the profit and loss analysis: $K_{6}$ - coefficient of profitability of production; $K_{7}-$ activity ratio of previous years; $K_{8}$ - the ratio of the largest amount of previously repaid loan;

- $\quad$ Group $G_{3}$ the efficiency of enterprise management: $K_{9}$ - terms of the existence of the enterprise; $K_{10}-$ the ratio of the company's funds in the cost of the loan project; $K_{11}$ - the ratio of own liquid assets.

To represent fuzzy knowledge, we propose to use one-dimensional membership functions, considering any type of input data. To build membership functions, a study was conducted to determine their type and type, as well as the parameters of membership functions based on the experience of credit experts and data sets on indicators, using financial statements of coal companies for 2020 (Ministry of Energy and Coal Industry of Ukraine, 2021). In the general case, some "absolute indicator" can be used, but this is not suitable for a real practical result of evaluation and comparison. Because achieving an "absolute indicator" in the evaluated conditions is an abstract concept.

Calculating the parameters of membership functions is a very important step and is a complex task, the solution of which depends on the adequacy of information modelling of fuzzy knowledge. Different mathematical or expert approaches can be used in different situations: search for parameters using the least-squares method or the Monte Carlo method; parameters can be built expertly based on the available initial data set, with their future adjustment; parameters can be considered in the form of reference values; use of various measures of proximity, etc.

In our study, we will use an expert approach based on the available initial data set. Therefore, the parameters are adjusted based on the financial statements of the coal industry of Ukraine for 2020 (Ministry of Energy and Coal Industry of Ukraine, 2021) by calculating the minimum and maximum values of the criterion.

Next, we will consider each indicator in more detail and construct their membership functions to reveal the uncertainty in the input data. 
Group $G_{1}$ the indicators of financial stability (Polishchuk \& Malyar, 2018).

1. The instantaneous liquidity ratio $K_{1}$ is the ratio of current financial investments and all cash to current liabilities. It is characterized by how quickly short-term liabilities can be repaid with highly liquid assets. That is, the company's ability to immediately eliminate short-term debt.

The criterion of instant liquidity can be represented as an s-shaped membership function:

$$
\mu\left(K_{1} ; \quad 0.2 ; \quad 0.25\right)=\left\{\begin{array}{clc}
0, & \text { if } & K_{1} \leq 0.2 ; \\
32\left(5 K_{1}-1\right)^{2}, & \text { if } & 0.2<K_{1} \leq 0.225 \\
1-50\left(1-4 K_{1}\right)^{2}, & \text { if } & 0.225<K_{1}<0.25 \\
1, & \text { if } & K_{1} \geq 0.25 .
\end{array}\right.
$$

2. The current liquidity ratio $K_{2}$ is the ratio of all receivables, current financial investments, and all cash to current liabilities. It is desirable that this ratio be greater than one. In this way, they determine whether the company has enough current assets to liquidate its debt completely. At the same time, under conditions of low liquid assets, the enterprise's financial condition may deteriorate, and too high liquidity will indicate a lack of use of current assets.

Therefore, we propose to present the criterion of the current liquidity ratio in the form of an s-shaped membership function:

$$
\mu\left(K_{2} ; \quad 0.5 ; \quad 1\right)=\left\{\begin{array}{clc}
0, & \text { if } & K_{2} \leq 0.5 ; \\
2\left(2 K_{2}-1\right)^{2}, & \text { if } & 0.5<K_{2} \leq 0.75 \\
1-8\left(1-K_{2}\right)^{2}, & \text { if } & 0.75<K_{2}<1 \\
1, & \text { if } & K_{2} \geq 1 .
\end{array}\right.
$$

3. Total liquidity ratio $K_{3}$ - defined as current assets divided by current liabilities.

The criterion of total liquidity is presented in the form of a triangular membership function:

$$
\mu\left(K_{3} ; \quad 1 ; 1.75 ; 2.5\right)=\left\{\begin{array}{clc}
0, & \text { if } & K_{3} \leq 1 \\
\frac{4\left(K_{3}-1\right)}{3}, & \text { if } & 1<K_{3} \leq 1.75 \\
\frac{10-4 K_{3}}{3}, & \text { if } & 1.75<K_{3}<2.5 \\
0, & \text { if } & K_{3} \geq 2.5 .
\end{array}\right.
$$

4. Coefficient of financial independence $K_{4}$ - characterizes the degree of independence of the enterprise from external borrowing. Defined as the ratio of the following costs and target financing, long-term liabilities, and current liabilities to equity. This ratio characterizes the share of equity in the total amount of funds advanced to its activities.

The membership function of the coefficient of financial independence can be represented as a triangular:

$$
\mu\left(K_{4} ; \quad 0 ; \quad 1 ; 2\right)=\left\{\begin{array}{clc}
0, & \text { if } & K_{4} \leq 0 \\
K_{4}, & \text { if } & 0<K_{4} \leq 1 \\
2-K_{4}, & \text { if } & 1<K_{4}<2 \\
0, & \text { if } & K_{4} \geq 2
\end{array}\right.
$$

5. Own funds maneuverability ratio $K_{5}$ - is defined as the difference between equity and non-current assets divided by equity. This indicator shows how mobile their own sources of funds are from a financial point of view. It is one of the main indicators of the impact of capital structure on the enterprise's profitability and may vary depending on the capital structure and industry affiliation of the enterprise. It is desirable that the coefficient of maneuverability increases slightly, but it is not advisable to allow a sharp increase, as it automatically decreases other indicators, such as the coefficient of autonomy, which leads to greater dependence of the company on creditors. function:

The criterion of maneuverability of own funds will be presented in the form of a triangular membership

$$
\mu\left(K_{5} ; \quad 0 ; \quad 0.5 ; \quad 1\right)=\left\{\begin{array}{clc}
0, & \text { if } & K_{5} \leq 0 \\
2 K_{5}, & \text { if } & 0<K_{5} \leq 0.5 \\
2-2 K_{5}, & \text { if } & 0.5<K_{5}<1 \\
0, & \text { if } & K_{5} \geq 1
\end{array}\right.
$$


Group $G_{2}$ the profit and loss analysis (Polishchuk \& Malyar, 2018).

1. Coefficient of profitability of production $K_{6}$ - the ratio of net profit of the enterprise and all operating costs. Characterizes the efficiency of investing in this production.

The criterion of profitability of production is presented in the form of an s-shaped membership function:

$$
\mu\left(K_{6} ; \quad 0.05 ; \quad 0,1\right)=\left\{\begin{array}{clc}
0, & \text { if } & K_{6} \leq 0.05 \\
2\left(20 K_{6}-1\right)^{2}, & \text { if } & 0.05<K_{6} \leq 0.075 \\
1-8\left(1-10 K_{6}\right)^{2}, & \text { if } & 0.075<K_{6}<0.1 \\
1, & \text { if } & K_{6} \geq 0.1 .
\end{array}\right.
$$

2. Activity ratio of previous years $K_{7}$. This ratio contains qualitative information about the profitable activities of the enterprise, which can be disclosed using fuzzy numbers. To analyze the profit and loss, we introduce the following gradation: $(0 ; 1]$ - unprofitable activity for the past two years or the report for the previous reporting year is not provided; $(1 ; 2]$ - unprofitable activity for the previous year; $(2 ; 3]$ - activity for no profit or loss, or no activity; $(3 ; 4]$ - profitable for the previous year; $(4 ; 5]$ - profitable for the past two years.

The criterion of activity of previous years will be presented in the form of an s-shaped membership function:

$$
\mu\left(K_{7} ; 1 ; 5\right)=\left\{\begin{array}{clc}
0, & \text { if } & K_{7} \leq 1 ; \\
\frac{\left(K_{7}-1\right)^{2}}{8}, & \text { if } & 1<K_{7} \leq 3 ; \\
1-\frac{\left(5-K_{7}\right)^{2}}{8}, & \text { if } & 3<K_{7}<5 ; \\
1, & \text { if } & K_{51} \geq 5 .
\end{array}\right.
$$

3. The ratio of the largest amount of previously repaid loan $K_{8}$. Defined as the ratio of the largest amount of received and repaid loan to the amount of the requested loan.

The criterion of the largest amount of previously repaid loan will be presented in the form of an s-shaped membership function:

$$
\mu\left(K_{8} ; \quad 0.8 ; 1\right)=\left\{\begin{array}{clc}
0, & \text { if } & K_{8} \leq 0.8 ; \\
2\left(5 K_{8}-4\right)^{2}, & \text { if } & 0.8<K_{8} \leq 0.9 \\
1-2\left(5-5 K_{8}\right)^{2}, & \text { if } & 0.9<K_{8}<1 \\
1, & \text { if } & K_{8} \geq 1 .
\end{array}\right.
$$

Group $G_{3}$ the efficiency of enterprise management (Polishchuk \& Malyar, 2018).

1. Criterion terms of the existence of the enterprise $K_{9}$ are specified in years of functioning. It can be represented as an s-shaped membership function in the range from 1 to 25 years:

$$
\mu\left(K_{9} ; \quad 1 ; 25\right)=\left\{\begin{array}{clc}
0, & \text { if } & K_{9} \leq 1 \\
\frac{\left(K_{9}-1\right)^{2}}{288}, & \text { if } & 1<K_{9} \leq 13 ; \\
1-\frac{\left(25-K_{9}\right)^{2}}{288}, & \text { if } & 13<K_{9}<25 \\
1, & \text { if } & K_{9} \geq 25 .
\end{array}\right.
$$

2. The ratio of the company's funds in the cost of the loan project $-K_{10}$. The ratio of the number of own funds in the investment and the loan amount is indicated.

The criterion of the share of enterprise funds in the cost of the loan project will be presented in the form of a linear s-shaped membership function:

$$
\mu\left(K_{10} ; \quad 0.2 ; \quad 0.4\right)=\left\{\begin{array}{clc}
0, & \text { if } & K_{10} \leq 0.2 \\
5 K_{10}-1, & \text { if } & 0,2<K_{10}<0.4 \\
1, & \text { if } & K_{10} \geq 0.4
\end{array}\right.
$$

3. The ratio of own liquid assets $-K_{11}$. That is the property that is free of obligations, as well as property that is offered as collateral for a new loan. This ratio is calculated as the ratio of the value of the company's own liquid assets to the amount of the requested loan.

The criterion for the availability of own liquid assets will be presented in the form of an s-shaped membership function: 


$$
\mu\left(K_{11} ; \quad 0.25 ; \quad 1\right)=\left\{\begin{array}{clc}
0, & \text { if } & K_{11} \leq 0.25 \\
\frac{2\left(4 K_{11}-1\right)^{2}}{9}, & \text { if } & 0.25<K_{11} \leq 0.625 \\
1-\frac{32\left(1-K_{11}\right)^{2}}{9}, & \text { if } & 0.625<K_{11}<1 \\
1, & \text { if } & K_{11} \geq 1 .
\end{array}\right.
$$

Thus, a set of 11 criteria for assessing the creditworthiness of coal enterprises is given, and their membership functions for data processing and comparison are constructed.

Fuzzy mathematical model for assessing the creditworthiness of enterprises.

An integrated model (Polishchuk \& Malyar, 2018) is presented, which will determine the borrower's rating based on membership functions. To do this, we build a mathematical model of decision-making, which based on the obtained estimates (set of input data) $V$ will determine for the enterprise $P$ its credit rating $D=\left(D_{1}, D_{2}, \ldots, D_{t}\right)$.

Let $K$ be the set of defined criteria used to evaluate some enterprise $P$. Define the measurement scale with the interval $[0 ; 1]$ and for each indicator $K_{i}(i=\overline{1, m})$ the membership functions $\mu\left(K_{i}\right) \in[0 ; 1]$ were determined. Next, each indicator $K_{i}$ will be described by the set $\left\{\mu\left(K_{1}\right), \mu\left(K_{2}\right), \ldots, \mu\left(K_{m}\right)\right\}$ of the corresponding numerical estimates.

Let the DM know or can assign weights to each efficiency criterion $\left\{v_{1}, v_{2}, \ldots, v_{m}\right\}$ from the interval $[0 ; 1]$, $l \in N$ (at the discretion of the expert and as he sees fit, for example, from 0 to 10 , or from 0 to 100). Then you can determine the normalized weights for each criterion:

$$
w_{i}=\frac{v_{i}}{\sum_{i=1}^{m} v_{i}}, i=\overline{1, m} ; w_{i} \in[0 ; 1]
$$

which meet the condition $\sum_{i=1}^{m} w_{i}=1$.

Consider the general case. Let us be given $n$ - enterprises of the coal industry $P=\left\{P_{1}, P_{2}, \ldots, P_{n}\right\}$, for which we need to determine the credit rating. The assessment of creditworthiness is determined using the following formula (Polishchuk \& Malyar, 2018):

$$
m\left(P_{j}\right)=\sum_{i=1}^{m} w_{i} \cdot \mu_{P_{j}}\left(K_{i}\right), j=\overline{1, n}
$$

Therefore, if $w=\left[w_{1}, w_{2}, \ldots, w_{m}\right]^{T}-$ vector of weighting factors, $M=\left[\begin{array}{ccc}\mu_{P_{1}}\left(K_{1}\right) & \ldots & \mu_{P_{1}}\left(K_{m}\right) \\ \cdot & \cdot & . \\ \mu_{P_{n}}\left(K_{1}\right) & \ldots & \mu_{P_{n}}\left(K_{m}\right)\end{array}\right]-$ matrix of values of membership functions for enterprises $P_{1}, P_{2}, \ldots, P_{n}$, then $M^{\prime}$ - vector of elements $m\left(P_{1}\right), m\left(P_{2}\right), \ldots, m\left(P_{n}\right)$, which determine the credit rating of an enterprise and it has the form:

$$
M^{\prime}=M \cdot W
$$

Therefore, the obtained estimate is compared according to the creditworthiness levels $D$, and the credit rating of the enterprise is determined. Example:

- The highest level of creditworthiness $m \in[0.57 ; 1]$ - rating AAA, AA. Very low expectations on credit risks and very high ability to repay financial obligations on time;

- High creditworthiness $m \in[0.37 ; 0.57]$ - rating A, BBB. Low credit risk expectations and ability to repay financial obligations on time;

- $\quad$ Speculative rating $m \in[0.19 ; 0.37]$ - rating BB, B. There is a possibility of credit risks, especially as a result of negative economic changes that may occur over time;

- Possible default $m \in[0.11 ; 0.19]-C C C$ rating. The rating says that default seems to be a real possibility. The ability to meet financial obligations depends entirely on a stable and favorable business or economic situation;

- Default inevitable $m \in[0 ; 0.11]$ - rating C, RD, D.

Thus, the built model allows to assess the creditworthiness of enterprises on the basis of performance indicators, reveals the uncertainty in the input data and takes into account the importance of criteria.

\section{Results}

To apply the concept of assessing the creditworthiness of the coal industry, we describe a general step-bystep algorithm.

1 step. For the considered enterprise $P$, we fill in input data $V$ using balances of reports. 
2 step. Based on the received input data, we calculate criteria of creditworthiness of the enterprises $K=$ $\left(K_{1}, K_{2}, \ldots, K_{11}\right)$.

3 step. We construct membership functions for the received criteria of creditworthiness of the enterprises, and we calculate their value $\left\{\mu\left(K_{1}\right), \mu\left(K_{2}\right), \ldots, \mu\left(K_{11}\right)\right\}$.

4 step. DM expresses its own views on the importance of criterion estimates $\left\{v_{1}, v_{2}, \ldots, v_{11}\right\}$, after which the normalized weights are calculated $\left\{w_{1}, w_{2}, \ldots, w_{11}\right\}$.

5 step. Using the weighted average convolution, we calculate the aggregate assessment of the creditworthiness of enterprises $m(P)$.

6 step. Let's compare the received aggregate estimation according to creditworthiness levels, and we will define a credit rating of the enterprise of the coal branch.

Thus, the algorithm of construction of the initial estimation consisting of six steps is described, and it is possible to develop the software on its basis.

As an experiment of the conducted research, we will carry out approbation for the definition of creditworthiness of the Lvivugol State Enterprise of Ukraine (Lvivugol State Enterprise, 2021). To do this, in step 1 , we will introduce indicators for the end of the reporting year from the financial statements (Ministry of Energy and Coal Industry of Ukraine, 2021), Table 1 (exchange rate $1 \mathrm{UAH}=0.0318$ EUR; 1 EUR $=31.879 \mathrm{UAH}$ ).

Tab. 1. Input data of the enterprise

\begin{tabular}{clcclc}
\hline № & \multicolumn{1}{c}{ Name } & [UAH] & № & Name & [UAH] \\
\hline 1 & All non-current assets & 971919 & 12 & Material costs & 727274 \\
2 & Receivables & 189216 & 13 & Salary expenses & 1535878 \\
3 & Other current receivables & 27983 & 14 & Deductions for social events & 353614 \\
4 & Current financial investments & 0 & 15 & Amortization & 158544 \\
5 & Cash and cash equivalents & 14760 & 16 & Other operating expenses & 315740 \\
6 & All current assets & 792701 & 17 & Term of existence of the enterprise & 18 \\
7 & All equity & 2777789 & 18 & Graduation of profit and loss analysis & 3 \\
8 & Securing future expenses and payments & 33356 & 19 & The largest amount of credit received and repaid & 25000000 \\
9 & All long-term liabilities & 150436 & 20 & The amount of the requested loan & 1500000 \\
10 & All current liabilities & 4291973 & 21 & The amount of own funds in the investment & 200000 \\
11 & Net profit (loss) & 450726 & 22 & The value of own liquid assets & 172000000 \\
\hline
\end{tabular}

Next, according to 2-3 steps based on input data, we calculate the evaluation criteria and their membership functions. The result of the calculation is presented in Table 2.

Tab. 2. The value of evaluation criteria and their membership function

\begin{tabular}{|c|c|c|c|}
\hline Criterion & The name of the criterion & $\begin{array}{l}\text { Estimation } \\
\qquad[K]\end{array}$ & $\begin{array}{c}\text { Membership function } \\
{[\mu(K)]}\end{array}$ \\
\hline$K_{1}$ & Instant liquidity ratio & 65.67 & 1 \\
\hline$K_{2}$ & Current liquidity ratio & 93.40 & 1 \\
\hline$K_{3}$ & Total liquidity ratio & 178.16 & 0 \\
\hline$K_{4}$ & Coefficient of financial independence & 2.95 & 0 \\
\hline$K_{5}$ & Coefficient of maneuverability of own funds & -17.68 & 0 \\
\hline$K_{6}$ & Coefficient of profitability of production & 0.17 & 1 \\
\hline$K_{7}$ & Activity ratio of previous years & 3 & 0.5 \\
\hline$K_{8}$ & The ratio of the largest amount of previously repaid loan & 16.67 & 1 \\
\hline$K_{9}$ & Terms of the existence of the enterprise & 18 & 0.83 \\
\hline$K_{10}$ & The ratio of the company's funds in the cost of the loan project & 1.33 & 1 \\
\hline$K_{11}$ & The ratio of own liquid assets & 114.67 & 1 \\
\hline
\end{tabular}

In the fourth step, DM determined the coefficients of importance of the criteria: $v=\{9 ; 8 ; 10 ; 7 ; 6 ; 8 ; 5 ; 7$; $8 ; 6 ; 10\}$. By formula (14) we calculate the normalized weights: $w=\{0.11 ; 0.10 ; 0.12 ; 0.08 ; 0.07 ; 0.10 ; 0.06$; $0.08 ; 0.10 ; 0.07 ; 0.12\}$.

In the fifth step, using the weighted average convolution, we calculate the aggregate assessment of the creditworthiness of enterprises according to $(15)-m(P)=0.693$. 
In the last step, we compare the obtained aggregate assessment according to the levels of creditworthiness and get that the Lvivugol State Enterprise of Ukraine has the highest level of creditworthiness.

Thus, the possibility of applying the developed fuzzy integrated model for assessing the creditworthiness of enterprises for the state-owned enterprise the Lvivugol State Enterprise is experimentally shown.

\section{Discussion}

The relevance of the intellectual analysis of knowledge using the apparatus of fuzzy sets proves the need to process data and obtain knowledge from them in various objects of study for further decision-making. In addition, the relevance of this study is confirmed by the European strategy for data (A European strategy for data, 2020) to implement it until 2030, to establish a leading model in the EU to follow the society endowed with data to improve solutions - in business and public sectors. In this context, the testing of fuzzy knowledge for indicators of creditworthiness assessment of Ukrainian coal industry enterprises was tested, which will be a model for other countries to follow.

The fuzzy mathematical model of creditworthiness assessment of enterprises developed in the research is based on the intellectual analysis of knowledge using the apparatus of fuzzy sets. The obtained assessment will increase the degree of validity of management decisions in the prevention of non-payment of loans, using both clear data from the balance sheets and a system of knowledge, considerations and experience of credit experts. The developed model will be a useful tool for financial institutions in lending to the coal industry of Ukraine.

The information model of fuzzy knowledge presentation in assessing the creditworthiness of Ukrainian coal industry enterprises and the developed fuzzy mathematical model of creditworthiness assessment of enterprises have a number of advantages, namely: accuracy, work with abstractions, transfer of information in a logically uniform way and increase the objectivity of expert and quantitative assessments; reveals the subjectivity of experts, a quantitative assessment is obtained; deduces for the considered enterprise of the coal industry an estimation of creditworthiness taking into account considerations of DM; deduces the linguistic level of ability to repay financial obligations on time. To apply the concept of assessing the creditworthiness of the coal industry, a general step-bystep algorithm is described that can be quickly implemented in the software product.

The disadvantages of this approach include the use of different models of convolutions to obtain an aggregate estimate, models of membership functions and the definition of their parameters, and all this can lead to ambiguity of the final results as well.

\section{Conclusions}

A study of the current problem of developing a fuzzy integrated model for assessing the creditworthiness of enterprises, based on the development of information models for the presentation of fuzzy knowledge in assessing the creditworthiness of the coal industry of Ukraine. This is the first time the following results have been obtained:

- The information model of presentation of fuzzy knowledge of creditworthiness assessment of Ukrainian coal industry enterprises is researched and developed. A set of 11 criteria for assessing the creditworthiness of enterprises and formed them into 3 groups: indicators of financial stability, analysis of profits and losses, the effectiveness of enterprise management. A membership function is constructed for each criterion, which will reveal the uncertainty in the input data, leading to a normalized form for comparison. To construct membership functions, a study was conducted to determine their type and type, as well as the parameters of membership functions based on the experience of credit experts and data sets on indicators, using real financial reports of Ukrainian coal industry enterprises for 2020;

- $\quad$ The improved fuzzy mathematical model for assessing the creditworthiness of enterprises, which reveals the vagueness of input data, derives the assessment of creditworthiness in view of DM considerations, determines the linguistic level of ability to repay financial obligations on time. Based on the built model, a general six-step algorithm is constructed, which can be quickly implemented into a software product;

- $\quad$ The developed information model of presenting fuzzy knowledge of creditworthiness assessment of coal enterprises of Ukraine and the improved fuzzy mathematical model were tested on real data of credit assessment of Lvivugol State Enterprise.

The rationality of the obtained assessment of the creditworthiness of enterprises proves the advantages of the developed model. The reliability of the obtained results is ensured by the correct use of the apparatus of fuzzy sets and membership functions, which is confirmed by the research results.

We see further research in the development of software in the framework of automation and security of decision-making by financial institutions, as well as the development of an information model for assessing the creditworthiness of the coal industry of Slovakia. The created tool can be applied to assess the creditworthiness of the company or in favor of a comparative analysis of the creditworthiness of selected companies in the coal industry in a selected country, respectively a company in Ukraine and a company in the European Union, etc. The importance and potential of the presented instrument as well as other current instruments to support decision- 
making in companies or at the level of states (regions) are growing in the context of expected measures and investments to meet the United Nations Sustainable Development Goals (SDGs, 2015), commitments under the signed and ratified Paris Climate Change Agreement (The Paris Agreement, 2015), within the framework of the climate-energy reform package "Fit for 55 package" (EU climate action and the European green Deal, 2021), which was presented by the European Commission, recovery and resilience facility plans of the countries of the European Union (Slovakia's recovery and resilience plan, 2021), etc.

\section{References}

A European strategy for data. (2020). Retrieved from: https://ec.europa.eu/info/sites/default/files/communicationeuropean-strategy-data-19feb2020_en.pdf

Bialy, W., Grebski, W., Galecki, G. \& Kaniak, W. (2020). Environmental Impact of The Mechanical Coal Processing Plant. Acta Montanistica Slovaca, 25(2), 139-149. https://doi.org/10.46544/AMS.v25i2.1

Chernikova, L.I., Faizova, G.R., Egorova, E.N., \& Kozhevnikova, N.V. (2015). Functioning and Development of Retail Banking in Russia. Mediterr. J. Soc. Sci., 6, 274-284. http://dx.doi.org/10.5901/mjss.2015.v6n6s4p274

Davydova, G. V., \& Belikov, A. (1999). Metodika kolichestvennoy otsenki riska bankrotstva predpriyatiy. Upravleniye riskom, (3), 13-20.

Endovytskyy, D. \& Bocharova, I. (2005). Analiz ta otsinka kredytospromozhnosti pozychalnyka: navchalnopraktych. KNORUS

EU climate action and the European Green Deal. (2021). Retrieved from: https://ec.europa.eu/clima/policies/eu-climate-action_en

Fainstein, G., \& Novikov, I. (2011). The comparative analysis of credit risk determinants in the banking sector of the Baltic States. Review of Economics \& Finance, 1(3), 20-45.

Fitch Ratings: Credit Ratings \& Analysis For Financial Markets. (2021). Retrieved from: https://www.fitchratings.com

Frydman, H., Altman, E. I., \& Kao, D. L. (1985). Introducing recursive partitioning for financial classification: the case of financial distress. The journal of finance, 40(1), 269-291.

International Convergence of Capital Measurement and Capital Standards. (2004). Basel Committee on Banking Supervision. Retrieved from: https://www.bis.org/publ/bcbs128.pdf

International Regulatory Framework for Banks. (2010). Basel Committee on Banking Supervision. Retrieved from: https://www.bis.org/bcbs/basel3.htm

Kelemen, M., Polishchuk, V., Gavurová, B., Andoga, R., \& Matisková, D. (2020). The Expert Model for Safety Risks Assessment of Aviation Environmental Projects' Implementation Within the Investment Phase of the Project. IREASE, 13(6), 198-207. https://doi.org/10.15866/irease.v13i6.18268

Kelemen, M., Polishchuk, V., Gavurová, B., Andoga, R., Szabo, S., Yang, W., Christodoulakis, J., Gera, M., Kozuba, J., Kal'avský, P., \& Antoško, M. (2020). Educational Model for Evaluation of Airport NIS Security for Safe and Sustainable Air Transport. Sustainability, 12, 6352. https://doi.org/10.3390/su12166352

Kelemen, M., Polishchuk, V., Gavurová, B., Rozenberg, R., Bartok, J., Gaál, L., Gera, M., \& Kelemen, M., Jr. (2021). Model of Evaluation and Selection of Expert Group Members for Smart Cities, Green Transportation and Mobility: From Safe Times to Pandemic Times. Mathematics, 9, 1287. https://doi.org/10.3390/math9111287

Kelemen, M., Polishchuk, V., Gavurová, B., Szabo, S., Rozenberg, R., Gera, M., Kozuba, J., Hospodka, J., Andoga, R., Divoková, A., \& Blišt’an, P. (2019). Fuzzy Model for Quantitative Assessment of Environmental Start-up Projects in Air Transport. Int. J. Environ. Res. Public Health, 16, 3585. https://doi.org/10.3390/ijerph16193585

Kjosevski, J., \& Petkovski, M. (2017). Non-performing loans in Baltic States: Determinants and macroeconomic effects. Balt. J. Econ, 1, 25-44. https://doi.org/10.1080/1406099X.2016.1246234

Kotsovsky, V., \& Batyuk, A. (2020). Representational capabilities and learning of bithreshold neural networks. In International Scientific Conference "Intellectual Systems of Decision Making and Problem of Computational Intelligence". Springer, Cham. https://doi.org/10.1007/978-3-030-54215-3 32

Kovalov, P. P. (2004). Kredytnyy reytynh kliyenta yak odyn z osnovnykh metodiv otsinky kredytospromozhnosti pozychalnyka. Formuvannya rynkovykh vidnosyn v Ukrayini, (12), 37-41.

Kravchenko, V. H., \& Kravchenko, T. V. (2021). Otsinyuvannya kredytospromozhnosti pozychal'nykiv komertsiynoho banku. Ekonomichnyy prostir, (167), 125-133. https://doi.org/10.32782/2224-6282/167-23

Leo, M., Sharma, S., \& Maddulety, K. (2019). Machine learning in banking risk management: A literature review. Risks, 7(1), 29. https://doi.org/10.3390/risks7010029

Lvivugol State Enterprise. (2021). Retrieved from: http://www.lvug.com.ua/lvivvugillya/ 
Malyar, M. \& Polishchuk, V. (2012). Nechitka model otsinky finansovoyi kredytospromozhnosti pidpryyemstv. Skhidno-Yevropeyskyy zhurnal peredovykh tekhnolohiy: matematyka $i$ kibernetyka - fundamentalni $i$ prykladni aspekty, 3/4(57). 8-16.

Marko, P., Mezhuyev, V. I., \& Velsh, D. (2020). Model dlya otsinky instrumentiv servisnoho upravlinnya u naftohazovoyi haluzi. Prykladni aspekty informatsiynykh tekhnolohiy, 3(4), 288-295. https://doi.org/10.15276/aait.04.2020.6

Meng, F. (2021). Safety Warning Model of Coal Face Based on FCM Fuzzy Clustering and GA-BP Neural Network. Symmetry, 13(6), 1082. https://doi.org/10.3390/sym13061082

Ministry of Energy and Coal Industry of Ukraine. (2021). Retrieved from: http://mpe.kmu.gov.ua/minugol/control/uk/publish/article?art_id=245525331\&cat_id=245194014

Orlova, E.V. (2021). Methodology and Models for Individuals' Creditworthiness Management Using Digital Footprint Data and Machine Learning Methods. Mathematics, 9, 1820. https://doi.org/10.3390/math9151820

Pestova, A., \& Mamonov, M. (2013). Macroeconomic and Bank-Specific Determinants of Credit Risk: Evidence from Russia. Economics Education and Research Consortium Working Paper Series, 13/10E.

Polishchuk, V. \& Malyar, M. (2018). Nechitki modeli i metody otsinyuvannya kredytospromozhnosti pidpryyemstv ta investytsiynykh proektiv: monohrafiya. RA "OUTDOR-SHARK".

Polishchuk, V. (2018). Fuzzy Method for Evaluating Commercial Projects of Different Origin. Journal of Automation and Information Sciences, 50(5), 60-73. https://doi.org/10.1615/JAutomatInfScien.v50.i5.60

Principles for the Management of Credit Risk. Basel Committee on Banking Supervision. (2000). Retrieved from: https://www.bis.org/publ/bcbs75.pdf

Shalev-Shwartz, S., \& Ben-David, S. (2014). Understanding machine learning: From theory to algorithms. Cambridge University Press.

Slovakia's recovery and resilience plan. (2021). Retrieved from: https://ec.europa.eu/commission/presscorner/detail/en/ip_21_3054

Smyrnov, V. O., Serhyeyev, P. V., \& Biletskyy, V. S. (2011). Tekhnolohiya zbahachennya vuhillya. Navchalnyy posibnyk. Donetsk: Skhidnyy vydavnychyy dim.

Tereshchenko, O. (2012). Novi pidkhody do otsinky kredytospromozhnosti pozychalnykiv-yurydychnykh osib. Visnyk Natsionalnoho banku Ukrayiny, (1), 26-30.

The United Nations Sustainable Development Goals. (2015). Retrieved from: https://www.undp.org/sustainable-development-goals

The Paris Agreement. (2015). Retrieved from: https://unfccc.int/process-and-meetings/the-paris-agreement/the-paris-agreement

World Coal Imports by Country. (2021). Retrieved from: https://www.indexmundi.com/energy/?product=coal\&graph=production\&display=rank

Xu, F., Ma, L., Liunata, L., Najaf, I. \& Streimikiene, D. (2020). Does Social Responsibility Increase Corporate Value of China's Coal Enterprises? The Mediating Effect of Capital Enrichment Based on the Generalized Moment Estimation. Acta Montanistica Slovaca, 25(3), 274-288. https://doi.org/10.46544/AMS.v25i3.2

Zaychenko, Y.P. (2008). Nechetkiye Modeli i Metody v Intellektualnykh Sistemakh: Navchalny Posibnyk. Slovo: Kiev, Ukraine. 